\title{
Threatening of Invasive Alien Species (IAS) on Vegetation Structure and Aerial Arthropod Diversity in Protection Area of UB Forest
}

\author{
Amalia Fadhila Rahma ${ }^{1}$, Endang Arisoesilaningsih ${ }^{2}$ \\ ${ }^{1}$ Magister Program of Biology, Department of Biology, Faculty of Mathematics and Natural Sciences, University of \\ Brawijaya, Malang, Indonesia \\ ${ }^{2}$ Department of Biology, Faculty of Mathematics and Natural Sciences, University of Brawijaya, Malang, Indonesia
}

\begin{abstract}
The aim of this study was to determine the vegetation structure of IAS and diversity of aerial arthropod under two level of invaded area. This study used quantitatively vegetation analysis methods for herbaceous, shrubs and tree plants through purposive plants sampling technique. Sampling areas were selected on two areas, divided into less and high invaded area of IAS. In each area, four sampling plots were randomly distributed with size $10 \times 10 \mathrm{~m} 2$ using nested sampling method. All plots area were marked using GPS and then identified, documented and calculated their density and dominance. Moreover, sampling arthropod was collected by sticky bite trap with white bread, rotten bananas and jackfruit as atractant. Invasive exotic plants found in sampling areas were Debregeasia orientalis, Brugmansia suaveolen, Debregeasia longifolia and Araliaceae. Aerial arthropod as pest were found both in less and high invaded area. Therefore, classification of protected forest in UB Forest vegetation is semi-natural system.
\end{abstract}

Keywords: arthropod, exotic, invasive alien species, UB Forest

\section{INTRODUCTION}

Protected Forest in UB Forest ecosystem is important because it is not only as a life support, but also natural biodiversity habitat [1]. Moreover, UB's protected forest has several risk factors associated with the threat to ecosystem integrity. Along with degradation, transformation of function protected forest as coffee garden, fragmentation and disturbance from human activities, invasive alien species (IAS) being one of the factors that poses a threat to integrity of protected forest in UB Forest [2].

Invasive alien species (IAS) are species whose introduction and/or spread outside their natural past or present distribution threatens biological diversity [3]. IAS have great effect on an ecosystem including cause of serious problem in new habitat such as change the evolution path of local species through competition, high adaptation capability result in dominating habitat and eliminating of local species. Invasion of $L$. camara can reduce the number of native species and harm the ecosystem. It has strong impact on the regeneration of native vegetation especially in the riparian areas where this plant can flourish. Therefore, the existence of IAS in new habitat tend to be harmful due to it

Correspondence address:

Endang Arisoesilaningsih

Email : earisoe@gmail.com

Address : Department of Biology, Faculty of Mathematics and Natural Sciences, University of Brawijaya, Malang potentiallythreaten the existing ecosystems and biodiversity [4];[5];[6].

In addition, many of evidence that invasions of alien species plant affect higher trophic levels. Arthropods provide an ideal model system to examine the effects of plant invasions on higher trophic levels. Studies indicate that shifts from native to invasive dominant plant species can reduce abundance and diversity of canopy arthropods and even change species composition. Their life history traits such as small body size, high reproductive rates, and short generation time translate into quick, easily measurable responses to environmental change compared with other organisms [7]. Therefore, understanding aerial arthropod responses to plant invasion helps expand our understanding of impacts on higher trophic levels.

The objective of this study was to determine the vegetation structure of IAS and variation of aerial arthropod important level under two level of IAS.

\section{MATERIAL AND METHOD}

Time and Setting of the Study

The study was conducted on November, $19^{\text {th }}$ 2016 at protected forest in UB Forest, Karangploso, Kabupaten Malang, East Java. Sampling areas were on along track at $7^{\circ} 49^{\prime} 29.30^{\prime \prime} S$ and $112^{\circ} 34^{\prime} 42.21^{\prime \prime}$. Area study was located at montainous region with elevation of $1200 \mathrm{~m}$ above sea level with fertile soil. 


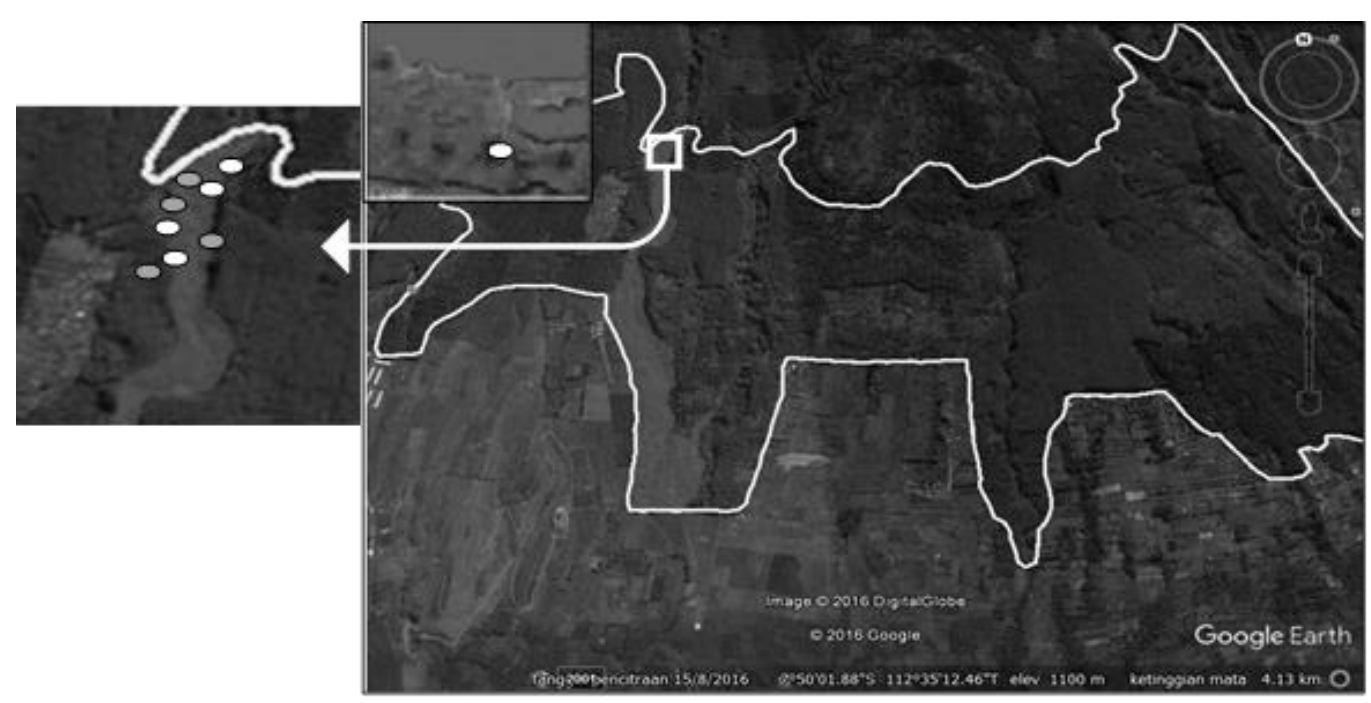

Figure 1. Location of sampling sites around the UB Forest. Note : $\bigcirc$ : less invaded area; $\bigcirc$ : high invaded area

\section{Data Collection and Analysis}

Vegetation sampling was carried out at eight randomly selected areas using purposive sampling technique based on the invasiveness level and then distributed into four sites in less and four sites in high invaded area (Figure 1). Meanwhile, invasiveness level was determined based on the abundance of excotic plant species in the area.

This research was quantitatively descriptive by using vegetation analysis method for herbaceous, shrubs and tree plants. Nested sampling plots with size $10 \times 10 \mathrm{~m}^{2}$ were applied in each sampling sites for tree. Smaller plots with $5 \times 5 \mathrm{~m}^{2}$ size were placed in the tree plots for shrubs vegetation and the smallest plot, $1 \times 1 \mathrm{~m}^{2}$, were also placed in the shrubs plots for herbaceous [8]. These plots were documented and marked the location using GPS. Arthropods were sampled in two sites, in less and invaded area. We used yellow sticky bite traps to sample the aerial arthropod community from 09.2012.10 a.m. The artractants that used were white bread, rotten bananas and jackfruit. The traps strung among the leaves. After collected, each arthropod species was calculated its density and abundance.

Coordinate data of sampling sites using GPS was imported to the computer. The data was analysed and mapped using Google Earth. While, vegetation and arthropod data were tabulated, analyzed the taxa species and IV using Microsoft Excel. Moreover, analyzed degree of endemism and naturalness index.

\section{RESULT AND DISCUSSION}

Taxa species of herbs, shrubs, trees and aerial arthropod in less invaded area was higher than high invaded area (Figure 2a). We found 11 herb species, 14 shrubs species, 5 trees species and 4 famili, 3 species aerial arthropod.

a)

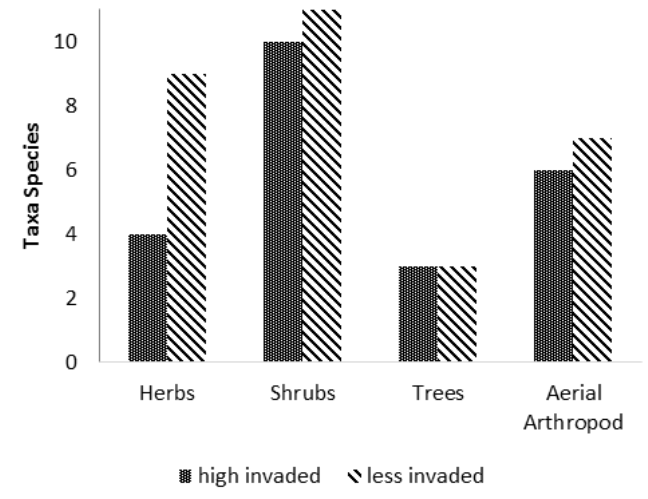

b)

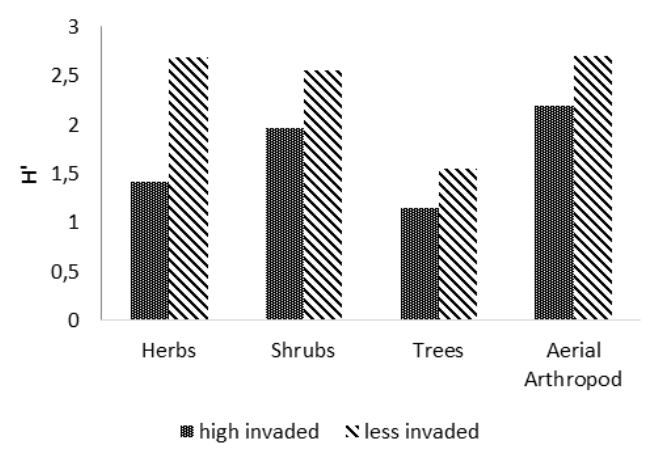

Figure 2. Community structure in high and less invaded area of IAS around protected forest in UB Forest

(a) Taxa species and (b) Plant and aerial arthropod Diversity Index

Herbs found were Debregeasia sp., Portulaca oleracea, Artherium sp., Brugmansia suaveolen, Homalomena sp., Clorantus elatior, Psychotria 
sp., Gesnericeae sp., Zyngeberaceae sp., Elastostema $s p$. Moreover, shrubs found were Pteridium aquilinum, Cychas rumphii, Debregeasia longifolia, Titonia ritondifolia, Amomum sp, Anthurium sp, Musa paradisiaca, Gigantochloa $s p$, Piper $s p$, Seedling Pileaceae $s p$, Pileaceae $s p$, Calliandra perturicensis, Pinanga coronata, Nenga pumila. And the trees were Ficus sp, Araliaceae, Ficus variegata, Schima wallichii, Engelhardia spicata. We are collected aerial arthropod were Saproxylic, Gryllus campestris, Aeolothripidae, Cicadellidae, Methoca ichneumonides, Tephritidae, and Philodromidae. The existence of invasive plants species had negative impact on biodiversity and agriculture ecosystem. Invasive plants would being competitor for other plants in terms of sunlight capturing, nutrients and water absorption and inhibited the growth of other plants through producing growth inhibitor compounds. In addition, invasive plants could dominate other habitat in order to eliminating local species [9]. Hence, high invaded area showed low diversity not only on plant but also aerial arthropod (Figure $2 \mathrm{~b}$ ).

An abundance of native species inless invaded area was higher than high area but not on trees vegetation (Figure 3). Native species was found six species in herbs (P. oleracea, Anthurium sp., Homalomena sp., C. eElatior, Psychotria sp., Gesneriaceae sp., Zingiberaceae sp., Elatostema sp., seedling Angiopteris sp.), eight species in shrubs (Amomum sp., F. elastica, N. pumila, Pileaceae sp. seedling, $P$. aquilinum, Gigantochloa sp., Pileaceae sp., P. coronata) and four species in trees (E. spicata, S.wallichii, F. variegata, Ficus sp.).

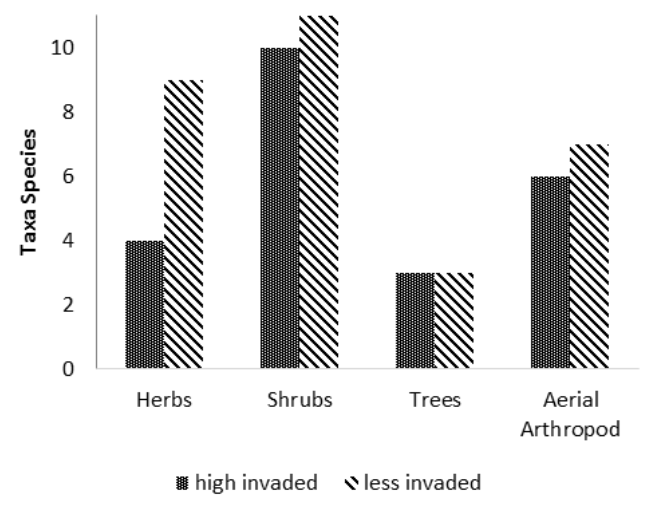

Figure 3. Degree of endemism in high and less invaded area of IAS around protected forest in UB Forest

Based on importance value index shown that precentage of exotic species was dominant in high invaded area than less but not in trees (Figure 4). In the high invaded areas were found $255,8 \%$ exotic herbs species consisting dominant of $D$. orientalis $160 \%$ and B. suaveolen $70,3 \%$. Moreover, $208 \%$ exotic shrubs species consisting dominant of D. longifolia $103 \%$ and the less invaded area was dominant too.
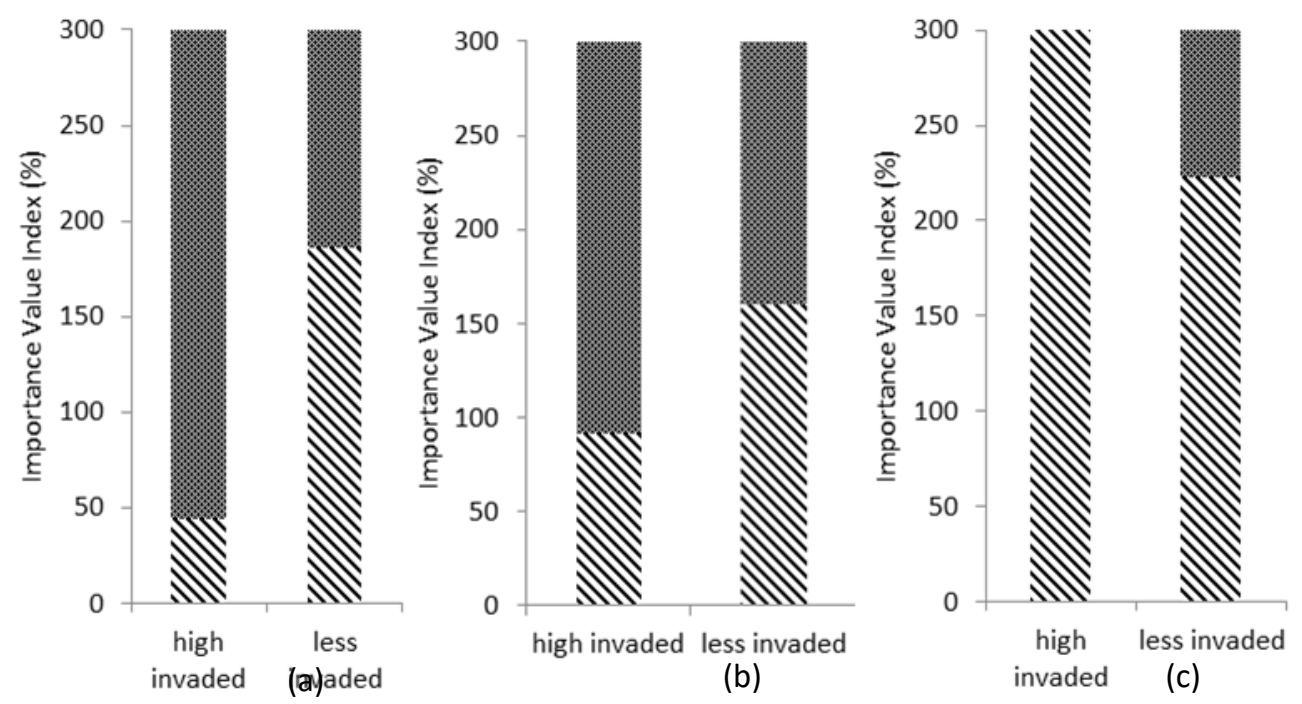

N Native Exotic

Figure 4. Plant species importance value index of native and exotic species in high and less invaded area of IAS (a) Herbs, (b) Shrubs, (c)Trees 
In the trees, exotic species was not found in high invaded area but less invaded area, only Araliaceae $77,1 \%$.

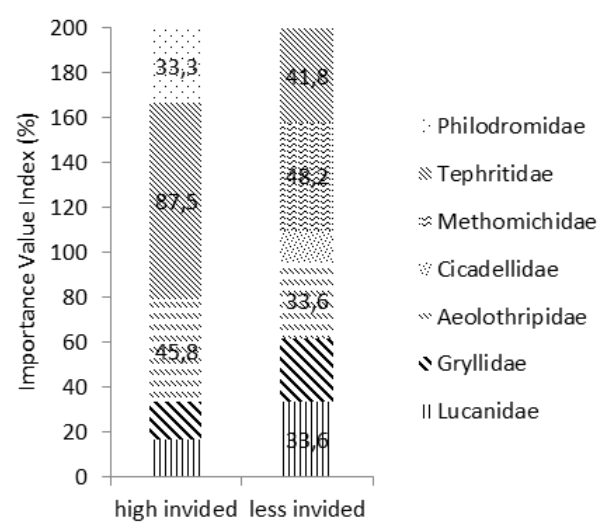

Figure 5. Aerial arthropod apecies importance value index in lower and lowest area of local plants

Furthermore, aerial arthropod was dominant in high invaded area is Tephritidae as pest while, Methoca ichneumonidae as parasitoid in less invaded area (Figure 5). In other side, were found saproxylic in less invaded area which indicated biodiversity and old growth forest [8].

In evaluating naturalness of vegetation, proteced forest of UB Forest included in seminatural system because possible dominance of wild exotic species so that native elements considerably reduced. Moreover, general dynamic still controlled by natural process and may include abandoned cultural system undergoing natural recovery [11].

\section{CONCLUSION}

Area surrounding the protected forest in UB Forest had been invaded by some dominated plants species such as Debregeasia orientalis, Brugmansia suaveolen, Debregeasia longifolia and Araliaceae. These invasive plants species had been decreased plant diversity and gave many negative impacts to environments. Furthermore, negative impact of plant invasion and forest structure on aerial arthropod communities showed the dominant of pest. Therefore, classification of protected forest in UB Forest vegetation is semi-natural system.

\section{ACKNOWLEDGEMENT}

Grateful thanks to Mr. Kiswoyo and who help authors to prepared this research. Sincere thanks also for Mr. Purnomo for guide author in forest area at UB Forest.

\section{REFERENCES}

[1]. Barbati, A., Corona, P. and Marchetti, M. 2007 A forest,typology for monitoring sustainable forest management: the case of European Forest Types. Plant Biosyst. 141, 93-103.

[2]. Fischer, A. and van der Wal, R. 2007 Invasive plant suppresses charismatic seavir-the construction of attitudes towards biodiversity management options. Biol. Conserv. 135, 256-267.

[3]. Mooney, H.A. dan Cleland, E.E. 2001. The evolutionary impact of invasive species. PNAS 10: 5446-5451.

[4]. Hakim, L., Leksono, A. S., Purwaningtyas, D., \& Nakagoshi, N. (2005). Invasive plant species and the competitiveness of wildlife tourist destination: A case of sadengan feeding area at Alas Purwo National Park, Indonesia. Journal of International Development and Cooperation, 12(1), 35-45.

[5]. Hakim, L., \& Miyakawa, H. (2015). Exotic plant species in the restoration project area in Ranupani recreation forest, Bromo Tengger Semeru Na-tional Park (Indonesia).

[6]. Wittenberg, R and Cock, M.J.W. 2003. Invasive Alien Species: A Toolkit Best Preventation and Management Practices. $\mathrm{CABI}$ Publishing. Cambridge

[7]. Hagen,E.N., J. D. Bakker, And Robert I. Gara. 2010. Aerial Arthropod Communities of Native and Invaded Forests, Robinson Crusoe Island, Chile. Environ. Entomol. 39(4): 1159-1164

[8]. Latifah, S. 2005. Teknik Analisis Hutan Alam. http://repository.usu.ac.id. Jurusan Kehutanan Universitas Sumatera Utara.

[9]. Gerber, E., C. Krebs, C. Murrell, M. Moretti, R. Rocklin, and U. Schaffner. 2008. Exotic invasive knotweeds (Fallopia spp.) negatively affect native plant and invertebrate assemblages in European riparian habitats. Biol. Conserv.141: 646654.

[10]. Müller, J., Bussler, H., Bense, U., Brustel, H., Flechtner, G.,Fowles, A. et al. 2005 Saproxylic beetles indicating structural qualities and habitat tradition. Waldoekologie 2: 106-113.

[11]. Machado, A. 2004. An Index of Naturalness. Journal for Nature Conservation.12: 95-100. 